\title{
PUBLIC AWARENESS AND ATTITUDES TOWARD EPILEPSY IN DIFFERENT SOCIAL SEGMENTS IN BRAZIL
}

\author{
ISABEL C. SANTOS*, MARILISA M.GUERREIRO*, ADRIANA MATA**, RENATA GUIMARÃES **, \\ LEDA FERNANDES* DJALMA C.MOREIRA FILHO***, CARLOS A.M.GUERREIRO*
}

\begin{abstract}
Purpose: To assess public awareness and attitudes toward epilepsy in Brazilians of different cultural and socioeconomic backgrounds. Background: Several studies have examined public awareness and attitudes toward epilepsy in various countries but there are no equivalent data for Brazil or South America. Material and Methods: We have applied the survey proposed by Caveness and Gallup , with some modifications and adaptations to four groups (I-IV) of subjects: I- 105 individuals accompanying patients to the Ophthalmologic outpatient clinic of the Hospital das Clínicas of the State University of Campinas (UNICAMP); II- 93 students recently admitted to medical and nursing school; III- 101 senior non-medical students; and IV- 69 senior medical students. Groups II, III, and IV were students at UNICAMP. Results: Individuals with a low socioeconomic standing had a poor profile of familiarity, knowledge and attitudes toward epilepsy. The pre-university and university students had a relatively good profile when compared to the published international polls. Senior medical students had an excellent level of familiarity and knowledge, but showed no change in their objection to having a son or a daughter marry an epileptic person. Conclusions: Our data suggest that there is a clear-cut relationship between the level of education and the individual's familiarity and attitudes toward epilepsy. Effective elimination of the prejudice toward epilepsy requires specific training and not just general, superficial information about the condition.
\end{abstract}

KEY-WORDS: epilepsy, attitude, prejudice, public awareness.

\section{Atitude e percepção sobre epilepsia em diferentes segmentos sociais no Brasil}

RESUMO- Com o objetivo de avaliar a percepção e a atitude em relação à epilepsia aplicamos questionário de 9 perguntas, modificado de Caveness e Gallup,1980. Foram entrevistados 105 acompanhantes de pacientes da Clínica de Oftalmologia do Hospital das Clínicas da UNICAMP (grupo I); 93 estudantes admitidos em 1996 nos cursos de medicina e enfermagem (grupo II); 101 estudantes do último ano de outros cursos, que não medicina (grupo III); e 69 estudantes do sexto ano do curso de medicina (grupo IV). Todos os estudantes eram da UNICAMP. Responderam que já tinham ouvido falar em epilepsia 87,6\% do grupo I e 100\% dos demais grupos. Com relação à causa da epilepsia responderam não sei ou respostas erradas: grupo-I 51,1\%, grupo-II 30,2\%, grupo-III 32,7\% e grupo-IV $0 \%$. Os autores discutem os seus achados comparativamente à literatura internacional pertinente e concluem que: 1. Há clara relação entre o nível educacional e familiaridade e atitude em relação à epilepsia; 2 . Eliminação efetiva do preconceito em relação à epilepsia exige treinamento específico e não informações superficiais, de cunho amplo sobre a condição. Estes dados suportam a noção de que campanhas nacionais devam ser realizadas para melhor esclarecimento leigo sobre as epilepsias, incluindo a população universitária.

PALAVRAS-CHAVE: epilepsia, atitude, preconceito, percepção.

Public awareness and attitudes toward epilepsy have been studied in the United States ${ }^{1}$, the Federal Republic of Germany ${ }^{2}$, Finland ${ }^{3}$, Italy ${ }^{4}$, China $^{5}$, Denmark ${ }^{6}$ and Taiwan ${ }^{7}$. We are unaware of any reports on this subject in Brazil or South America. Epilepsy is still shrouded in misinformation

Faculdade de Ciências Médicas da Universidade Estadual de Campinas (FCM/UNICAMP), Campinas, Brasil: *Departamento de Neurologia, **Estudante do Curso de Enfermagem, ***Departamento de Medicina Preventiva e Social. Aceite: 11-dezembro-1997.

Dr. Carlos A. M. Guerreiro- Depatamento de Neurologia, FCM-UNICAMP - Caixa Postal 6111 - 13083-970 Campinas SP - Brasil. 
and misbelief ${ }^{8}$. Social discrimination against epileptic persons can reflect in the quality of life of these individuals, and may have serious consequences for them?. The concept of quality of life includes the individual's perceptions about his or her condition ${ }^{10}$, and there is evidence that the social atmosphere may have an important influence on the adaptation and rehabilitation of an epileptic person $^{11}$, as well as in personality development ${ }^{12}$.

In this study, we have applied the survey of Caveness and Gallup ${ }^{1}$, with minor modifications and adaptations, to four different groups of individuals: a low socioeconomic level population, preuniversity students, senior non-medical university students and senior medical students. The major goals of this survey were to obtain some information on the public awareness and attitudes toward epilepsy, to correlate the responses received with the individual's cultural and socioeconomic background and to compare these data with those of studies carried out in other countries.

\section{MATERIALS AND METHODS}

We translated and adapted the questionnaire proposed by Caveness and Gallup ${ }^{1}$ (Table 1) into Portuguese. The composition of the questionnaire included demographic data (age, sex, occupation, region of birth, and education) as well as nine questions: Q1. Have you ever heard or read about the disease called "epilepsy" or convulsive seizures or epileptic fits? Answer: yes or no; Q2. Did you ever know anyone who had epilepsy? Answer: yes or no; Q3. Have you ever seen anyone who was having a seizure? Answer: yes or no; Q4. Would you object to having any of your children in school or at play associate with persons who sometimes had seizures? Answer: yes, no or I do not know; Q5. Would you object to having a son or daughter of yours marry a person who sometimes has seizures? Answer: yes, no or I do not know; Q6. Would you employ someone with epilepsy? Answer: yes, no or I do not know; Q7. Do you think epilepsy is a form of insanity? Answer: yes, no or I do not know; Q8. Do you think the epileptic person would be able to do your job? Answer: yes, no or I do not know; Q9. What do you think is the cause of epilepsy?

Before deciding upon the final form, we performed a pre-test in 30 low socioeconomic level individuals in order to gain some idea of the receptivity to and adequacy of the nomenclature used. In its final form, the questionnaire was applied by three of us (one senior medical student and two third-year nursing students) through personal interviews on the university campus of the State University of Campinas (UNICAMP) and in the university hospital. A total of 368 individuals were interviewed as follows: Group I: 105 persons accompanying patients to the Ophthalmologic outpatient clinic of the Hospital das Clínicas, UNICAMP; Group II: 93 students recently admitted to the university medical and nursing school; Group III: 101 senior non-medical students; Group IV: 69 senior medical students. Group I individuals were assumed to represent the general population attending the hospital (a general university hospital), and had a lower socioeconomic level than the other groups. During their neurology course, the subjects in Group IV received 6 hours of teaching dealing with the basic concepts, classification, investigation and treatment of epilepsies, including three 20-30 minute explanatory videos exhibiting seizures. In their fifth medical year, this group had also attended the epilepsy outpatient clinic at least once (4 hours). All individuals in groups II, III, and IV were students at UNICAMP.

When the answer to Question 1 of the questionnaire was no we closed the interview. Questions 1 to 3 had two options (yes and no) and Questions 4 to 8, in addition to yes and no, had the option "I do not know". Question 9 was open and the answers were framed in: Don't know, Brain or central nervous system disorders, Heredity (inherited disease), Mental or emotional disorders, Other (specific diseases, trauma) and Miscellaneous (idiopathic, unknown).

\section{Statistics}

The statistical methods utilized were the Chi-square test for contingency tables and their partition (Yate's corrected in two-fold tables), and Fisher's exact test ${ }^{13}$.

\section{RESULTS}

The data related to the age, occupation, sex, education and place of birth of the subjects are presented in Table 1. The responses to questions about familiarity with epilepsy are summarized in Table $2 \mathrm{a}$ and those to questions related to attitudes toward epilepsy are given in Table $2 \mathrm{~b}$. The answers to Question no.9 are provided in Table 3. 
Table 1. General information on the individuals in Groups I to IV.

\begin{tabular}{|c|c|c|c|c|c|c|c|c|}
\hline \multirow[b]{2}{*}{ Age (yr) } & \multicolumn{2}{|c|}{$\begin{array}{l}\text { Group I } \\
(15-82 \mathrm{yr})\end{array}$} & \multicolumn{2}{|c|}{$\begin{array}{c}\text { Group II } \\
(17-24 \mathrm{yr})\end{array}$} & \multicolumn{2}{|c|}{$\begin{array}{c}\text { Group III } \\
(19-44 \text { yr) }\end{array}$} & \multicolumn{2}{|c|}{$\begin{array}{l}\text { Group IV } \\
(21-33 \mathrm{yr})\end{array}$} \\
\hline & $\mathrm{n}$ & $\%$ & $\mathrm{n}$ & $\%$ & $\mathrm{n}$ & $\%$ & $\mathrm{n}$ & $\%$ \\
\hline $15-25$ & 20 & 19.0 & 93 & 100 & 87 & 86.0 & 57 & 82.6 \\
\hline $26-35$ & 19 & 18.1 & & & 12 & 12.0 & 12 & 17.4 \\
\hline $36-45$ & 30 & 28.6 & & & 2 & 2.0 & & \\
\hline $46-55$ & 11 & 10.5 & & & & & & \\
\hline $56-65$ & 14 & 13.3 & & & & & & \\
\hline $66-82$ & 11 & 10.5 & & & & & & \\
\hline \multicolumn{9}{|l|}{ Occupation } \\
\hline Students & 5 & 4.8 & 93 & 100 & 101 & 100 & 69 & 100 \\
\hline Other & 100 & 95.2 & & & & & & \\
\hline \multicolumn{9}{|l|}{ Sex } \\
\hline Female & 60 & 57.1 & 49 & 52.7 & 67 & 66.3 & 31 & 45 \\
\hline Male & 45 & 42.9 & 44 & 47.3 & 34 & 33.7 & 38 & 55 \\
\hline \multicolumn{9}{|l|}{ Education } \\
\hline 1st-4th grade & 48 & 45.7 & & & & & & \\
\hline 5th-8th grade & 23 & 21.9 & & & & & & \\
\hline \multicolumn{9}{|l|}{ Secondary level } \\
\hline (High School) & 17 & 16.2 & 93 & 100 & & & & \\
\hline University & 8 & 7.6 & & & 101 & 100 & 69 & 100 \\
\hline Illiterate & 9 & 8.6 & & & & & & \\
\hline \multicolumn{9}{|l|}{ Place of Birth } \\
\hline Campinas & 24 & 22.9 & 19 & 20.4 & 22 & 21.8 & 15 & 21.7 \\
\hline São Paulo State & 77 & 73.3 & 62 & 66.7 & 62 & 61.4 & 42 & 60.9 \\
\hline Other State & 4 & 3.8 & 12 & 12.9 & 17 & 16.8 & 12 & 17.4 \\
\hline
\end{tabular}

\section{DISCUSSION}

The present study represents a group-specific survey rather than a nation-wide opinion poll. This type of study has to be analyzed cautiously in view of the particular methodology applied. Our samples are considerably smaller than those of other authors. Some of the questions are theoretical (Questions 4, 5 and 6) and the individual may answer them in a "politically correct" manner. The main problem with this questionnaire is that it treats epilepsy as an entity, while much depends on the severity of the epilepsy, whether you do or not object to a marriage in the family and again much depends on the type of epilepsy and the type of work whether you do or do not hire a person with epilepsy.Some of these aspects have been discussed in the literature ${ }^{3}$. Despite these limitations, this approach has been employed in several countries $^{1-7}$.

For analysis, we considered Group I to represent the general population, although we are aware that it cannot accurately represent the true population of the city of Campinas, Brazil. Group II represents the high school population or pre-university students, again it cannot be considered to be truly representative. Group III represents the university undergraduate students and group IV is the "almost medical doctors" population and is the "gold standard" for knowledge and attitudes toward epilepsy in intergroup comparisons. The fundamental differences among the groups are: Group I is older, less educated and economically poorer than Group II; Group II is younger and less academically educated than Group III; Group III is not as trained in medical affairs and epilepsy as is Group IV.

Table 4 compares the familiarity with epilepsy among various studies. Our Group I data are similar to those of Taiwan. The pre-university and university populations showed a very good profile 
Table 2a. Responses to questions about familiarity with epilepsy.

\begin{tabular}{ccccccc}
\hline Group (n) & \multicolumn{2}{c}{ Q 1 } & \multicolumn{2}{c}{ Q 2 } & \multicolumn{2}{c}{ Q 3 } \\
& Yes (\%) & No (\%) & Yes (\%) & No (\%) & Yes (\%) & No (\%) \\
\hline I (105) & 87.6 & 12.4 & 68.5 & 31.5 & 72.8 & 27.2 \\
II (93) & 100 & - & 47.3 & 52.7 & 34.4 & 65.6 \\
III (101) & 100 & - & 71.3 & 28.7 & 71.3 & 28.7 \\
IV (69) & 100 & - & 92.8 & 7.2 & 97.1 & 2.9 \\
\hline
\end{tabular}

Table 2b. Responses to attitudes toward epilepsy.

\begin{tabular}{cccccccccccccccc}
\hline Group (n) & \multicolumn{3}{c}{ Q 4 } & \multicolumn{3}{c}{ Q 5 } & \multicolumn{3}{c}{ Q 6 } & \multicolumn{2}{c}{ Q 7 } & \multicolumn{2}{c}{ Q 8 } \\
& $\begin{array}{c}\text { Yes } \\
(\%)\end{array}$ & $\begin{array}{c}\text { No } \\
(\%)\end{array}$ & $\begin{array}{c}\text { Don't } \\
\text { know } \\
(\%)\end{array}$ & $\begin{array}{c}\text { Yes } \\
(\%)\end{array}$ & $\begin{array}{c}\text { No } \\
(\%)\end{array}$ & $\begin{array}{c}\text { Don't } \\
\text { know } \\
(\%)\end{array}$ & $\begin{array}{c}\text { Yes } \\
(\%)\end{array}$ & $\begin{array}{c}\text { No } \\
(\%)\end{array}$ & $\begin{array}{c}\text { Don't } \\
\text { know } \\
(\%)\end{array}$ & $\begin{array}{c}\text { Yes } \\
(\%)\end{array}$ & $\begin{array}{c}\text { No } \\
(\%)\end{array}$ & $\begin{array}{c}\text { Don't } \\
\text { know } \\
(\%)\end{array}$ & $\begin{array}{c}\text { Yes } \\
(\%)\end{array}$ & $\begin{array}{c}\text { No Don't } \\
(\%)\end{array}$ & $\begin{array}{c}\text { know } \\
(\%)\end{array}$ \\
\hline I (105) & 2.2 & 93.5 & 4.3 & 30.4 & 47.8 & 21.7 & 16.3 & 10.9 & 72.8 & 5.4 & 82.6 & 12.0 & 65.2 & 27.2 & 7.6 \\
II (93) & 4.3 & 77.4 & 18.3 & 8.6 & 63.4 & 28.0 & 68.8 & 2.2 & 29.0 & - & 100 & - & 79.6 & 7.6 & 12.9 \\
III (101) & 4.0 & 90.1 & 5.9 & 15.8 & 68.3 & 15.8 & 71.3 & 8.9 & 19.8 & - & 97 & 3.0 & 92.1 & - & 7.9 \\
IV (69) & 4.3 & 94.2 & 1.4 & 24.6 & 63.7 & 11.6 & 72.5 & 11.5 & 15.9 & - & 100 & - & 84.0 & 13.0 & 2.9 \\
\hline
\end{tabular}

Q1. Have you ever heard or read about the disease called "epilepsy" or convulsive seizures or epileptic fits?

Q2. Did you ever know anyone who had epilepsy?

Q3. Have you ever seen anyone who was having a seizure?

Q4. Would you object to having any of your children in school or at play associate with persons who sometimes had seizures?

Q5. Would you object to having a son or daughter of yours marry a person who sometimes has seizures?

Q6. Would you employ someone with epilepsy?

Q7. Do you think epilepsy is a form of insanity?

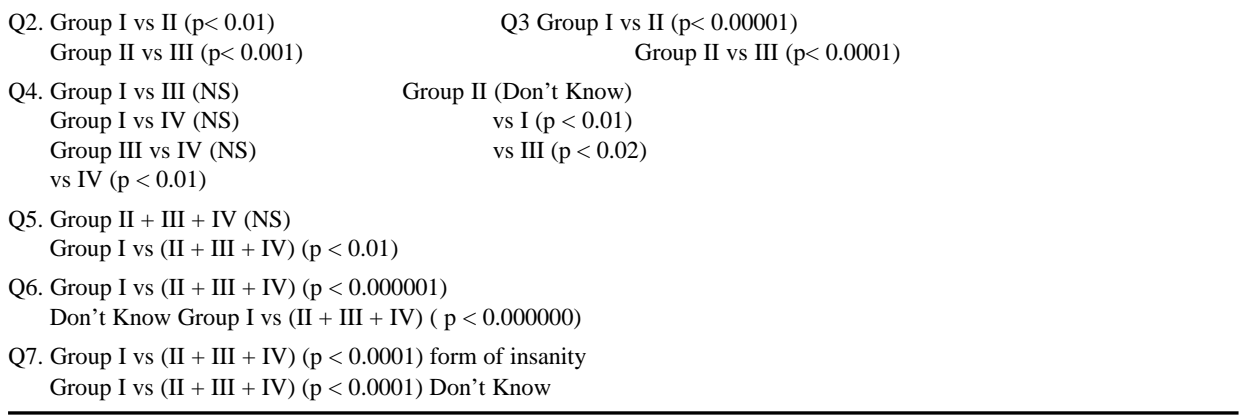

of familiarity with epilepsy, although the first of these had met fewer people with epilepsy or had seen fewer people undergoing seizures.

The familiarity with epilepsy of the pre-university group (Group II) was similar to that of the Finnish study ${ }^{3}$. The university group (Group III) was comparable to the general population of Denmark and indeed had better scores.

The responses to the questions about attitudes toward epilepsy are shown in Table 5. Our general population (Group I) had more objections to their children marrying or employing an epileptic 
Table 3. Response to the question (Q9): "What do you think is the cause of epilepsy?"

\begin{tabular}{lcccc}
\hline Response & $\begin{array}{c}\text { Group I } \\
\%(\mathrm{n}=92)\end{array}$ & $\begin{array}{c}\text { Group II } \\
\%(\mathrm{n}=93)\end{array}$ & $\begin{array}{c}\text { Group III } \\
\%(\mathrm{n}=101)\end{array}$ & $\begin{array}{c}\text { Group IV } \\
\%(\mathrm{n}=69)\end{array}$ \\
\hline Don't know & $28.3(26)$ & $29.1(27)$ & $29.7(30)$ & - \\
Brain or central nervous system disorders & $17.4(16)$ & $61.3(57)$ & $52.5(53)$ & $68.1(47)$ \\
Heredity (inherited disease) & $15.2(14)$ & $4.3(4)$ & $4.0(4)$ & - \\
Mental or emotional disorders & $22.8(21)$ & $1.1(1)$ & $3.0(3)$ & - \\
Miscellaneous (specific diseases, trauma, etc.) & $10.9(10)$ & $1.1(1)$ & $1.0(1)$ & - \\
Other (idiopathic, unknown) & $5.4(5)$ & $3.3(3)$ & $9.9(10)$ & $31.9(22)$ \\
\hline
\end{tabular}

Mental or emotional disorders: $\quad$ I vs (II + III) $(\mathrm{p}<0.00001)$

$$
\text { II vs III (NS) }
$$

Don't know

I vs (II + III) (NS)

Table 4. Responses to questions about familiarity with epilepsy.

\begin{tabular}{|c|c|c|c|c|c|c|}
\hline Country & $\begin{array}{c}\text { Year study } \\
\text { was conducted }\end{array}$ & $\mathrm{N}$ & $\begin{array}{l}\text { Q } 1 \\
\text { Yes }\end{array}$ & $\begin{array}{l}\text { Q 2 } \\
\text { Yes }\end{array}$ & $\begin{array}{l}\text { Q 3 } \\
\text { Yes }\end{array}$ & References \\
\hline West Germany & 1978 & 2000 & 90 & - & - & 2 \\
\hline Finland 1978 & 2272 & 95 & 49 & 45 & 3 & \\
\hline United States & 1979 & 1539 & 95 & 63 & 59 & 1 \\
\hline Italy 1983 & 1043 & 73 & 61 & 52 & 4 & \\
\hline China 1988 & 1278 & 93 & 77 & 72 & 5 & \\
\hline Denmark1992 & 1038 & 97 & 60 & 50 & 6 & \\
\hline Taiwan 1992 & 2610 & 87 & 70 & 56 & 7 & \\
\hline \multicolumn{7}{|l|}{ Brazil } \\
\hline $\begin{array}{l}\text { "general } \\
\text { population" }\end{array}$ & 1996 & 105 & 88 & 69 & 73 & \\
\hline $\begin{array}{l}\text { "preuniversity } \\
\text { population" }\end{array}$ & 1996 & 93 & 100 & 47 & 34 & \\
\hline $\begin{array}{l}\text { "university } \\
\text { population" }\end{array}$ & 1996 & 101 & 100 & 71 & 71 & \\
\hline "medical doctors" & 1996 & 69 & 100 & 92 & 97 & \\
\hline
\end{tabular}

Q1. Have you ever heard or read about the disease called "epilepsy" or convulsive seizures on epileptic fits?

Q2. Did you ever know anyone who had epilepsy?

Q3. Have you ever seen anyone who was having a seizure? 
Table 5. Responses to questions about attitudes toward epilepsy

\begin{tabular}{lccccccc}
\hline \multicolumn{1}{c}{ Country } & $\begin{array}{c}\text { Year study } \\
\text { was conducted }\end{array}$ & $\mathrm{N}$ & $\begin{array}{c}\text { Q 4 } \\
\text { Yes }\end{array}$ & $\begin{array}{c}\text { Q 5 } \\
\text { Yes }\end{array}$ & $\begin{array}{c}\text { Q 6 } \\
\text { Yes }\end{array}$ & $\begin{array}{c}\text { Q 7 } \\
\text { Yes }\end{array}$ & References \\
\hline West Germany & 1978 & 2000 & 23 & - & 20 & 23 & 2 \\
United States & 1979 & 1539 & $6(5)$ & $18(14)$ & $9(5)$ & $3(5)$ & 1 \\
Italy & 1983 & 1043 & $11(9)$ & - & 15 & $8(13)$ & 4 \\
China & 1988 & 1278 & 57 & 87 & 53 & 16 & 5 \\
$\begin{array}{l}\text { Denmark } \\
\text { Taiwan }\end{array}$ & 1992 & 1038 & 7 & - & 7 & 1 & 6 \\
$\begin{array}{l}\text { Brazil } \\
\begin{array}{l}\text { "general } \\
\text { population"* }\end{array}\end{array}$ & 1996 & 2610 & 18 & 72 & 31 & 7 & 7 \\
$\begin{array}{l}\text { "preuniversity } \\
\text { population"* }\end{array}$ & 1996 & 105 & $2.0(4.3)$ & $30.4(21.7)$ & $16.3(72.8)$ & $5.4(12.0)$ & \\
$\begin{array}{l}\text { "university } \\
\text { population"* }\end{array}$ & 1996 & 93 & $4.3(18.3)$ & $8.6(28.9)$ & $68.8(29.0)$ & $0(0.0)$ & \\
"medical & 1996 & 101 & $4.0(5.9)$ & $15.8(15.8)$ & $71.3(19.8)$ & $0(0.0)$ & \\
doctors"* & 69 & $4.3(1.4)$ & $24.6(11.6)$ & $72.5(15.9)$ & $0(0.0)$ & \\
\hline
\end{tabular}

* "Don't know" option in parenthesis.

Q4. Would you object to having any of your children in school or at play associate with persons who sometimes had seizures? Q5. Would you object to having a son or daughter of yours marry a person who sometimes has seizures?

Q6. Would you employ someone with epilepsy?

Q7. Do you think epilepsy is a form of insanity?

person than did the other groups. The individuals in this group were less informed about the etiology of epilepsy; they thought of epilepsy as a form of insanity or, more frequently than the others, did not know the cause.

Interestingly, an increasing familiarity with epilepsy did not change the attitudes toward epilepsy. For instance, the "medical doctors" objected to a son or daughter marrying an epileptic person to the same extent as Groups I and III, and all of these groups objected more than Group II. Similar data were obtained in China ${ }^{5}$ where education reduced the respondent's prejudice against play and employment, but did not change their objection to marriage, including in the group which the authors classified as the "medical profession".

We found that 51, 30, 32 and $0 \%$, respectively, of the individuals in groups I,II,III, and IV gave wrong answers (mental or emotional disorders) or declared that they did not know the causes of epilepsy. Fifty-seven percent of Chinese ${ }^{5}, 42 \%$ of Taiwanese $7,36 \%$ of Finns ${ }^{3}$, $40 \%$ of southern Italians ${ }^{4}$ and $41 \%$ of Americans ${ }^{1}$ were ignorant of the causes of epilepsy. Thirty and $32 \%$ of Groups II and III (pre-university and university students) had similar levels of knowledge to the general population in studies from other countries. These data indicate that there is a clear-cut relationship between the level of general education and knowledge about epilepsy and that specific information or training can positively modify this. Our data also suggest that younger individuals tend to have less knowledge than older Groups (II vs III), although the better education of Group III may have been an influencing factor. 
Interestingly, Mason et al. ${ }^{14}$ showed that medical students undertaking seminars on epilepsy had a significant improvement in their overall knowledge, but not in their attitudes.

Despite the methodological limitations of this type of study, these results point to the need for educating the public, including (young) university students, about epilepsy.

\section{REFERENCES}

1. Caveness WF, Gallup GH Jr. A survey of public attitudes toward epilepsy in 1979 with an indication of trends over the past thirty years. Epilepsia 1980; 21:509-518.

2. Finke M. Public attitudes toward epilepsy in the Federal Republic of Germany: trends over the past decade. Epilepsia 1980;21:201.

3. Iivanainen M, Uutela A, Vilkkumaa I. Public awareness and attitudes toward epilepsy in Finland. Epilepsia 1980;21:413-423.

4. Canger R, Cornaggia C. Public attitudes toward epilepsy in Italy: results of a survey and comparison with U.S.A. and West German data. Epilepsia 1985;26:221-226.

5. Lai CW, Huang X, Lai YHC et al. Survey of public awareness, understanding, and attitude toward epilepsy in Henan Province, China. Epilepsia 1990;31:182-187.

6. Jensen R, Dam M. Public attitude toward epilepsy in Denmark. Epilepsia 1992;33:459-463.

7. Chung MY, Chang YC, Lai YHC et al. Survey of public awareness, understanding, and attitudes toward epilepsy in Taiwan. Epilepsia 1995;36:488-493.

8. McLin WM, de Boer HM. Public perceptions about epilepsy. Epilepsia 1995; 36:957-959.

9. de Boer HM. Epilepsy and society.Epilepsia 1995:36(Suppl):S8-S11.

10. Souza EAP, Guerreiro MM. Qualidade de vida. In Guerreiro CAM, Guerreiro MM (eds.) Epilepsia. São Paulo: Lemos Editorial, 191-199.

11. Sonnen AEH. How do live with epilepsy. In Dam M and Gram L (eds). Comprehensive epileptology. New York: Raven Press, 1990: 753-767.

12. Viberg M, Blennow G, Polski B. Epilepsy in adolescence: implication for the development of personality. Epilepsia 1987;28:542-546.

13. Fleiss J. Statistical methods for rates and proportions. 2Ed, New York: John Wiley and Sons, 1981.

14. Mason C, Fenton GW, Jamieson M. Teaching medical students about epilepsy. Epilepsia;1990;31:95-100. 